\title{
LINGUISTIC ANALYSIS ON JAVANESE LANGUAGE SELOGUDIG-AN DIALECT IN SELOGUDIG, PAJARAKAN, PROBOLINGGO
}

\author{
Lusi Nur Aini (Corresponding Author) \\ Department of Language and Literature, Faculty of Language and Literature \\ Kanjuruhan University of Malang \\ Jln. S. Supriadi No. 48 Malang 65148, East Java, Indonesia \\ Phone: (+62) 82-301-732-015Ｅ-mail: lusi1699@gmail.com \\ Arining Wibowo \\ Department of Language and Literature, Faculty of Language and Literature \\ Kanjuruhan University of Malang \\ Jln. S. Supriadi No. 48 Malang 65148, East Java, Indonesia \\ Phone: (+62) 85-646-389-803Ｅ-mail: cacamarisa90@yahoo.com \\ Maria G. Sriningsih \\ Department of Language and Literature, Faculty of Language and Literature \\ Kanjuruhan University of Malang \\ Jln. S. Supriadi No. 48 Malang 65148, East Java, Indonesia \\ Phone: (+62) 85-933-033-177～E-mail: m.g.sriningsih@gmail.com
}

\begin{abstract}
Linguistic analysis is an analysis of language study which include language form, language meaning, and language in context. Study of linguistic can learn the kind of approaches in language. For example, grammar, language and culture, like the study of cultural discourses and dialects is the domain of sociolinguistics, which looks at the relation between linguistic variation and social structures. Language is one of human characteristics because people living with language. Indonesia is well known of one thousand islands country and as 1000 languages country. So, in Indonesia, there are many vernaculars from each ethnicity in every region of Indonesia. Javanese language has the most speakers of the existing another language speakers. As a language that has a lot of speakers, Javanese language has a lot of kinds or dialect forms as a result of the space and time process. One of the examples is Selogudig-an language which is found in Probolinggo district, especially in Selogudig village, Pajarakan sub-district, Probolinggo district. From the linguistic aspects, Selogudig-an language is a dialect of the Javanese language. To analyze this research, the researcher used descriptive qualitative research design. It is intended to describe about how Javanese language Selogudig-an dialect is formed, the phonological, lexical and accent differences of Javanese language Selogudig-an dialect.
\end{abstract}

Key words: Lingusitic Analysis, Javanese Language, Selogudig-an Dialect. 


\section{Introduction}

Dialect is a language who used by people who live in the area or region that are different from another people who are neighborhood. Dialect is one of the human language which become become an identity of that region that region. Each human language is a complex of knowledge and abilities enabling speakers of the language to communicate with each other, to express ideas, hypotheses, emotions, desires and all the other things which need expressing. It can be said that linguistic is the study of these knowledge systems in all their aspects: how such a knowledge system structured is, how it acquired is, how it used in the production and comprehension of messages is and how it can be changed overtime is.

One of human characteristics is language, because in daily life, people living with language. There is no people in this world who is living without language. Language is considered to be an exclusively human mode of communication. Language is very important which is used by people in a particular area to interact and communicate with the others society. Typically, society is consisting of various social status and different background. Language will continue to grow and develop along with growth and development of the user. That is as a consequence that languages which are existing in this world have variations. Relating with language variation, there are three terms that need to be known, which is hooked idiolects with language variation individual, dialect is a language variation used by a group of society in a place or a time, and a wide variation the language used in a particular situation (Ayatrohaedi, 2002:7).

Indonesia is well known of 1000 islands country and as 1000 languages country. So, in Indonesia, there are many vernaculars from each ethnicity in every region of Indonesia. Although Indonesian has many vernaculars, but, Indonesia still has unity language, it is called by Indonesian language as the national language.

Javanese language has the most speakers of the existing another language speakers. Javanese People or Javanese language speakers have high latitude hence the spread of Javanese language to be more spread evenly in Indonesia. As a language that has a lot of speakers, Javanese language has a lot of kinds or dialect forms as a result of the space and time process.

One of the examples on the paragraph above is Selogudig-an language which is found in Probolinggo district. From the linguistic aspects, Selogudig-an language is a dialect of the Javanese language. The term of the Selogudig-an language usage refers on the generality of people who are outside of Selogudig area who is calling Javanese language used by Selogudig Group such as Selogudig-an language because the village housed in Selogudig and speakers called Wong Selogudig.

The existence of Selogudig-an language because the regions in Probolinggo which is dominance by 
Madurese people tend to use Madurese Language and culture. However, there are some people like Selogudig group stick with the original Javanese language and Probolinggo culture although in some aspects there is the influence of Madurese in Selogudig group.

From the language aspect, the language which is used by Selogudig language is classified as a Javanese Language of Selogudig-an dialect. Javanese language Selogudig-an dialects occur naturally due to the mixing of several languages, these are Javanese (language used by Javanese people or the speakers who are used it), Madurese (language used by Madurese people or the speakers who are used it) and Osing (language used by Banyuwangi people). Selogudig-an language said as the Old Javanese language because Selogudig-an language does not have undhak usuk as a modern Javanese language. Besides not having undhak usuk, Selogudig-an language has old Javanese language vocabulary which is still used by the only elderly. The vocabulary of Javanese language in this case as a possible influence of Osing language in Banyuwangi which is a relic area of old Javanese language. This also makes the Selogudig-an language is different from other Javanese dialect in Javanese area.

\section{Literature review \\ Language}

Language is an important thing in society. It is not only means for communication and interaction but also establishing and maintaining human relationship. Language generally is defined as a means of communication in social life. One of characteristics of a language is social. All human being use languages to interact with other person in the society. Language is not only used an instrument of communication but also as a means of individual society language is not instinctive. It has to be learned as a system of arbitrary conventional symbol. The term of language can be used in several definitions. Therefore, here need distinguished some understanding of the language in accordance with the objectives and expertise (linguist). In science of language (linguistics), language defined by a sound symbol system. Socially and language sociolinguistic also defined as a social legacy in the form of speech or also a symbol of unity of society. According to Wardhaugh (2006), language is an important means of communication that demonstrates human social behavior. It is a human identity, and that is why we use language to send and receive messages about who we are, where we are from, and whom we are associated with. Its role in the society makes it interesting and necessary to live; it is compressive in that humanity needs it. It plays a crucial role in social interaction and is an allimportant agent in the transmission of cultural and social values.

Every society needs language in their daily life. Individually, we need 
language to convey everything which comes from our heart. We use language not only to convey and share our information, concepts, ideas or even feelings, in the sense of the word as a means of conveying something but also we use it to reveal our personal identity, our character and our background. With language, it makes easy to communicate with stranger involve speaking.

\section{Language Variation}

Each language has more than one variety, especially in the way in which it is spoken. People may not only speak in one language but also the language to interaction with their group in their daily life and each language has it is certain characteristics, which cause the variety of a language. Hudson (1980: 24) states that language variation is a set of linguistics items with similar social distribution. Language variation is every language used by a group of people in society. According to Yule that each language has more than one variety, especially in the way in which it is spoken. People may not only speak in one language but also the language to interaction with their group in their daily life and each language has it is certain characteristics, which cause the variety of a language. Richards and Jack (2002: 557) argued that "language variation refers to the differences in pronunciation, grammar, or word choice within a language, which may be related to regional, social class, and educational background to the degree of formality of a situation in which language is used". It means that the various regions, social class, and educational background may cause a variety of a language.

It can be concluded that language variation is a language used by a group of people which is determined the situation and society who belong to a community of language.

\section{Linguistics}

Linguistics is the scientific study of language which is three aspects to this study. The three aspects of it are language form, language meaning, and language in context. In linguistics, human language is a system of sounds, symbols and meaning. There are many branches of linguistics which is studying each function of language. Phonetic is the study of acoustic, visual, and articulatory properties in the production and perception of speech and non-speech sounds. The study of language meaning, on the other hand, deals with how languages encode relations between entities, properties, and other aspects of the word to convey, process, and assign meaning, as well as to manage and resolve ambiguity. While the study of semantic typically concerns itself with truth conditions, pragmatic deal with how context influences meanings. Another branch is Grammar, a system of rules which govern the language of a particular speech community. It encompasses of sound, meaning, and gestures, and includes phonology which the study how sounds and gestures function together, morphology is the study of 
the formation and composition of words, and syntax is the study of formation and composition of phrases and sentences from words. Lado (1978: 15) "Linguistics is the science that describes and classifies languages". The linguist identifies and describes the units and the pattern of the sound system of the word morphemes, the phrases, and sentences that is the structure of language.

Within the practical science, linguistics is one of the social sciences because language is part of the actions of men and women society. Linguistics can be broadly broken into three categories or subfield: the study of language form, of language meaning, and of language in context.

\section{Sociolinguistics}

The term of sociolinguistics is a branch of linguistics which take language as an object of the study. In a way which is usually distinguished from how syntax, semantic, morphology and phonology. According to Hudson (1980: 4) that "sociolinguistic is the study of language in relationship to society". The use of a language has to appropriate to the context in which it is used. While Holmes (1992: 6) argued that "sociolinguistics is the study of the relationship between language, and society by identifying the social functions of language and the way it is used to convey social meaning". Thus it can be said that sociolinguistics is the study of what kind of language used in social context. Wardhaugh (2006: 13) stated that sociolinguistics is concerned with investigating the relationships between language and society with the goal being a better understanding of the structure of language and of how languages function in communication. Sociolinguistics is including of three aspects: language, society, and the relation between language and society. Sociolinguistics is a term including the aspect of linguistics applied toward the connection between language and society, and the way we use it in different social situation. It ranges from the study of the wide variety of dialects across a given region down to the analysis between the way men and women speak to other. Sociolinguistics often shows us the humorous realities of human speech and how a dialect of a given language can often describe the age, sex and social class of the speakers, it codes the social function of a language. In other side, sociolinguistics also shows symbols used to represent language in society.

\section{Dialect}

The term of dialect is language system who used by some people that are different from another people who are neighborhood but used some solid system, and also dialect is a part of certain language used in certain area to communicate with each other. In area where many languages are spoken it will appear the characteristic of each language. There are similarities and also some differences among them. A 
language changes in time and space. Everyone has their own word or style of communication and every group of speakers use a certain language, and that is called dialect. According to Suratmi (1996: 6) dialect is the technical names for what American usually thinks as an accent strictly speaking, accent refer only differences as pronounciation between one varietie of language and other. But dialect refer to all of the differences of languages, those all pronounciation, word, usage and syntax.

The dialect is a variety of languages spoken by groups of people in a place or certain areas (geographical dialect). Dialect is also a linguistic system used by a society to distinguish it from other neighboring communities which use different systems although closely related, or in other words a difference in unity and unity in diversity.

\section{Kind of Dialect \\ Regional Dialect}

According to Wardhaugh (1998: 42) geography dialect is the term used to describe attempts made to map the distribution of various linguistic features so as to show their geographical provenance.

\section{Social Dialect}

Social dialect also usually determined by a range of features, such as residential area, income level, education, etc. it refers to differences in the way of language is spoken by particular group of people in specific region. For example, people who live in palace use a kind of dialect based on their social status.

\section{Research Methodology Research Design}

In this research, the researcher identifies the Javanese Language Selogudig-an Dialect which still exist in Selogudig, Pajarakan, Probolinggo. In conducting this research, the researcher uses qualitative research in the research design by observing and identfying the Selogudig-an Dialect. The researcher use qualitative research design because it provides valuable insights into the local perspectives of the population studied. The great contribution of qualitative research is the culturally specific and contextually rich data it produces. Such data are proving critical in the design of comprehensive solutions to problems in various disciplines and also this kind of research must use social experience in conducting the data for this research, and also in this research describe more for finding this research result.

Qualitative research is based on a naturalistic research, ethnography research, casus research, and analysis research. It views reality as multilayered, interactive, and a shared social experience interpreted by individuals. Most of description and interpretation are portrayed with words rather than numbers.

The researcher adopts Moleong's opinion about descriptive qualitative research. Moleong (1988:2) affirms that qualitative research is a type of research which does not include any calculation or enumerating. Further 
Moleong explains that a qualitative research is the research of which the data in the form of written or oral word are descriptively analyzed. Based on this, the type of this study is descriptive, since the data are not enumerating., but they are written and oral words .

\section{Data and Source of Data}

In this research focused on the analysis of Javanese Language Selogudig-an dialect which is used by society of Selogudig, Pajarakan, Probolinggo who housed in the village for a long time. Meanwhile, the main data is taken from the conversation between Selogudig society who housed long time in Selogudig, Pajarakan, Probolinggo and the researcher who is entered the village for observing this dialect. From of the data can be limited into some part such limitation of age, limititation of sex, and limitation of education. Another data is researcher's own documentation and experience like interview which is done by the researcher with society and daily conversation from people who live in Selogudig, Pajarakan, Probolinggo. Source of the data are word, phrase, and sentence in Selogudig-an dialect used by society in their daily life. Since, the researcher was taking the data, the researcher found some differences on Selogudig-an dialect such as phonological differences, lexical differences, and accent differences.

\section{Instrumentation}

In conducting this research, the researcher herself is the main instrument in collecting the data. It means that the researcher planned everything dealing with the research. The researcher collects, classifies, and analyzes the study by herself without any help from other people. The instruments used by the researcher are observation, interview, field note, and corpuses.

\section{Observation}

Observation is a method of data collection in which the situation of interest is watched and the relevant facts, actions and behaviors are recorded. Ary (2002) says "qualitative observation goal is to complete the description of behavior in a specific natural setting". It means that there is no manipulation of the subjects' behavior. This observation was participant's observation. It means that the writer went inside to get information.

In this research, the observation was done by observing and collecting Javanese language Selogudig-an Dialect which is still used by Selogudig society. The researcher comes to the Selogudig village which is located in Pajarakan, Probolinggo. The researcher observes Selogudig-an dialect directly to the people and society who are housed in Selogudig, Pajarakan, Probolinggo.

\section{Interview}

According to Ary (2006), interviews are used to gather data on subjects' opinions, beliefs, and feelings about the situation in their own words. The 
interview is one of the most widely used methods for obtaining qualitative data.

The researcher interviews some people who have competence about Selogudigan Dialect, especially the opinions from society of Selogudig who are lived long time in Selogudig Village. So that the researcher can identify Selogudig-an dialect which still exist in Selogudig's Javanese language. To support this interview, the researcher also use recording in order to get validation of the data. Recording is research instrument to obtain the data concerning with the research subject condition by using recorder to record all of the data.

\section{Field Note}

When observing a culture, setting, or social situation, field notes are created by the researcher to remember and record the behaviors, activities, events and other features of the setting being observed. Field notes are meant to be read by the researcher to produce meaning and an understanding of the culture, social situation or phenomenon being studied.

The researcher uses this kind of instrument to collect informations when the researcher communicate with people in Selogudig, because sometimes there are some important information on their spontan opinion.

\section{Corpuses}

Corpus is a body writing of the researcher. In this research, corpuses used a collection data noted by the researcher, such as: example of conversation in the daily life of
Selogudig'society. This instrument used by the researcher in order to ease the analysis and finding the solution of making shorter and clasify a plenty of the data. The corpuses on this research is contained the phonological differences, lexical differences and accent differences between Selogudigan dialect and Javanese, Madurese and Osing because Javanese language Selogudig-an dialects occur naturally due to the mixing of several languages, these are Javanese Madurese and Osing.

\section{Data Collection}

In conducting this research, the researcher has some steps to collect the data are follows: (1) Conducting observation by observing the condition and environment of population. The researcher came directly to the society that was observed. (2) Making approach to the society. The researcher made socialization and adaptation in using Javanese Language in daily activities. (3) Collecting the data from the society that was observed. (4) Making notes on the dialect that were used by the informant. (5) Making conversation between the researcher and the informant. (6) Making informal interview and ask the meaning that informants used. (7) Taking notes and record the interview in the recorder. (8) Comparing all of the data which is taken from informant.

\section{Data Analysis}

Moeloeng ( 2004 ) stated that the data analyzing is organizing process in 
which the data are made in order with certain pattern, category and a unit of the basic explanation. In this research, the researcher analyzed all the data taken from the two cities. The step to analyzed the data are follows as (1) Separating all of the data obtained from the sample in term of their differences like phonological differences, lexical differences, and accent differences. (2) Comparing al of the data to know the differences. (3) Analysis all of the data to know the differences. (4) Clasifying all of the data to know the result of differences.

\section{Trustworthiness of the Data}

In this part, to get more validation of the data, it should be tested using data triangulation. Data triangulation involves using different sources of information in order to increase the validity of a study. This is one of important techniques to measure the data which is conducted by the researcher can be trusted or not. In Extension, these sources are likely to be stakeholders in a programparticipants, other researchers, program staff, other community members, and so on. In the case of Javanese Language Selogudig-an dialect, the research would start by observing Selogudig village, the researcher make a socialization with the society. And then, the researcher make an interview with the society of Selogudig in order to collect the data of dialect which is still used by society. After the researcher make observation and interview, the researcher compare the result of observation with the interview. In the end of this part, the researcher discussed the data that the researcher got with one of Selogudig society who is really understand about Javanese Language Selogudig-an dialect for asking opinion about Selogudig-an dialect and for getting more informations and different ideas which are useful in this research. They are Mr. Deki Sampurno, S.Pd as a Selogudig Wetan society, he is a teacher in one of Junior high school in Probolinggo, he is fivety one years old, and Mrs. Bebli Rajesh Punjabi as a student in one of Junior high school in Paiton.

\section{Research Findings}

In this research findings, the researcher made observation in Selogudig Village, especially at Dusun Sadeng RT 01 RW 02, Selogudig Wetan Village, Pajarakan Sub-district, Probolinggo district. The observation started at Friday May 22, 2015 and it finished at Tuesday June 02, 2015. During the observation, the researcher lived at Mr. Syaifullah's house, so, the researcher was easy to conducted the observation.

The Process Formed of the Javanese

\section{Language Selogudig-an Dialect}

From the observation which was done by the researcher, there were many data and informations which are got during the observation. Society of Selogudig usually call the Javanese language which is used by them in their daily life as "Bahasa Selogudig" and in English means Selogudig language.

Language of Selogudig is hereditary language which has existed since a 
long time ago. According to the informant from Selogudig Wetan village which hold an interview by the researcher, Selogudig language caused by people who came to the Selogudig village especially Madurese people who gave an influence in their daily language. Basically, society of Selogudig in their daily life use Javanese language, because a lot of Madurese people who live in that region, so, Selogudig language was formed. The usage of a regional language which is used Javanese language but the patois (dialect) and the accent use Madurese language.

In usage of Selogudig language, there are also some vocabularies and terms of Osing language, a vernacular from Banyuwangi, East Java. But, the usage of all the vocabularies and terms are only limited on old people of Selogudig society. The term of Osing language which is often used by society until now is "riko" in english means "you". It is not only old people use this term but also the children and young man of Selogudig society use "riko" in their daily conversation. This term is still used by the society because of the utterance which is very easy for Selogudig society. Another example of Osing language's usage is "klendai" in English means "where are you going", but the word is used among elderly.

Generally people or society outside of Selogudig village call the Javanese language which is used by Selogudig society as "Bahasa Jawa Dak-gladak" whose meaning in English is messy Javanese Language because of the usage of that language. The language uses lower Javanese language (in Jvanese language, there three levels of language, they are Ngoko: the lower level, Kromo: the middle level and Inggil: the highest level) and Madurese language's patois (dialect) and accent. The outside people of Selogudig village assume that the Javanese language which is used by Selogudig society as Javanese language is only uttered by them without knew the real meaning of Javanese language is.

Madurese people is the majority society in Selogudig village. In the daily life, society of Selogudig uses Madurese language and Selogudig language. And also there are terms of Madurese language inserted to Javanese language sentence. For example "kiah" in Indonesian language means "juga" and in English means "but". The example of sentence usage, "eroh kiah aku" in Indonesian language means "Saya mengetahui juga" and in English means "I also know".

The original Selogudig society not only know and understand Selogudig language but also Madurese language. They use Selogudig language and Madurese language in their daily life.

The term of the Selogudig-an language usage refers on the generality of people who are outside of Selogudig village who is calling Javanese language used by Selogudig society such as Selogudig-an language because the name of area that they live is Selogudig village. People who are outside of Selogudig village call Selogudig language because the name is very easy 
to be remembered.

Phonological Differences of Javanese Language Selogudig-an Dialect

At the level of phonological vowel and consonant phonemes in the Selogudig language have differences from the Javanese language in general. That is because the vowel phonemes Selogudig language has been much influenced by the vowel phonemes of Madurese language. Society of Selogudig is familiar with the use of words or phonemes of Madurese language.

Phoneme /o/

Phoneme /o/ at word "ron loronan" in Selogudig language, in Javanese language is "loroan" and in English means "both". Phoneme /o/ in "ron loronan" pronounced as [o] like in phoneme /o/ of Madurese language. The example of phoneme $/ \mathrm{o} / \mathrm{in}$ Madurese language is "colo" ", in Indonesian language means "mulut" and in English means mouth". The pronunciation of word "ron loronan" same as the pronunciation of word "colo" ". In general, phoneme /o/ in Selogudig language is influenced by Madurese language. So, the pronunciation of phoneme $/ \mathrm{o} /$ is pronounced as $/ \mathrm{o} /$.

Phoneme /e/

Phoneme /e/ in Selogudig language is also influenced by phoneme /e/ in Madurese language. Word "cetteg" in Selogudig language, in Indonesian language means "mata kaki" and in English means "ankle". Phoneme /e/ is pronounced as [ é ] like in Madurese language. The example of phoneme /e/ is pronounced as [é] in Madurese language is "sesek", in indonesian language means "sesak nafas" and in English means "breathless". The pronunciation of word "cetteg" same as the pronunciation of word "sesek". Both of phonemes, phoneme $/ \mathrm{o} /$ and phoneme /e/, the pronunciation are influenced by Madurese language. Society of Selogudig are very familiar with the Madurese language's pronunciation because there are many Madurese people in that region who are used Madurese language in daily conversation.

\section{Lexical Differences of Javanese Language Selogudig-an Dialect}

From the data which are taken during observation, there are some terms which are only used by Selogudig society. The terms of Selogudig language are original terms from Selogudig. But, the Selogudig language terms are very different from Javanese language, and Javanese people do not understand what the meaning is. The usage of Selogudig language in the sentence same as Javanese language and the differences are explained below.

A. Noun

1. Wangan

Word "parit" in English means "ditch", in Selogudig language is "wangan", while in Javanese is "selokan" but both of them have same meaning in Indonesian language.

Example in sentence:

Selogudig language : Air ndek 
wangan entek.

Javanese language : Air ndek selokan entek.

Indonesian language : Air di parit itu kosong.

English language : The water in the ditch was empty.

\section{B. Verb}

\section{Weneono}

Word "memberikan" in English means "give", in Selogudig language is "weneono", while in Javanese language is "kekno" but both of them have same meaning in Indonesian language.

Example in sentence:

Selogudig language : Weneono hp ku nang Qinan.

Javanese language : Kekno hp ku nang Qinan.

Indonesian language : Berikan hp ku ke Qinan.

English language : Give my handphone to Qinan.

\section{Dun-jandun}

Word "mengobrol" in English means "chating", in Selogudig language is "dun-jandun", while in Javanese language is "jagongan" but both of them have same meaning in Indonesian language.

Example in sentence:

Selogudig language : Dun- jandun mbek Nuril ndek ngarep.

Javanese language : Jagongan mbek Nuril ndek ngarep.

Indonesian language : sedang mengobrol dengan Nuril di teras.

English language : Chating with
Nuril in terrace.

C. Adjective

1. Magiyan

Word "lebih cepat" in English means "faster", in Selogudig language is "magiyan", while in Javanese language is "ndang" but both of them have same meaning in Indonesian language.

Example in sentence:

Selogudig language : magiyan! Wes bengi iki.

Javanese language : ndang! Wes bengi iki.

Indonesian language : Lebih cepat! Sudah malam.

English language : Let's be faster! It have been night.

\section{Epaya}

Word "lelah" in English means "tired", in Selogudig language is "epaya", while in Javanese language is "kesel" but both of them have same meaning in Indonesian language.

Example in sentence:

Selogudig language : Aku epaya mari teko lantai 4.

Javanese language : Aku kesel mari teko lantai 4.

Indonesian language : Saya lelah baru datang dari lantai 4.

English language : I am tired after cameback from fourth floor.

\section{Cerrek}

Word "dekat" in English means "near", in Selogudig language is "cerrek", while in Javanese language is "cedeg" but both of them have same 
meaning in Indonesian language.

Example in sentence:

Selogudig language : Mlaku ae yo, cerrek ae.

Javanese language : Mlaku ae yo, cedeg ae.

Indonesian language : Jalan kaki saja, jaraknya dekat.

English language : It is so near, we go there on foot.

D. Adverb

1. Mang

Word "tadi" in English means "just now", in Selogudig language is "mang", while in Javanese language is "mau / maeng" but both of them have same meaning in Indonesian language.

Example in sentence:

Selogudig language : Konco mu wes muleh iki mang.

Javanese language : Konco mu wes muleh iki mau.

Indonesian language : Teman mu sudah pulang tadi.

English language : Your friend went home just now.

\section{2. $\mathrm{Coi}$}

Word "ini" in English means "this", in Selogudig language is "coi", while in Javanese language is "iki" but both of them have same meaning in Indonesian language.

Example in sentence:

Selogudig language : Semongko coi enom.

Javanese language $\quad$ : Semongko $i k i$ enom.

Indonesian language : Semangka ini masih muda.

English language :

This

watermelon is stlill raw.

3. Assa

Word "kesana" in English means "there", in Selogudig language is "assa", while in Javanese language is "rono" but both of them have same meaning in Indonesian language.

Example in sentence:

Selogudig language : Assa wes kamu nyang pak guru.

Javanese language : Rono wes kamu nyang pak guru.

Indonesian language : Kamu kesana ke pak guru.

English language : You go there to the teacher.

\section{Accent differences of Javanese} Language Selogudig-an Dialect

The accent is used in Javanese language Selogudig-an dialect (society of Selogudig called it as Selogudig language) resembles the accent in Madurese language than the accent in Javanese language. Moreover, there is no Javanese language's accent in Selogudig language in general. If society of Selogudig begin to converse, it does not sound like the Javanese peope who speak Javanese language but it sounds like people who speak Madurese language. If Javanese people pronounce some words or a word, it sounds very viscous of Javanese language or people commonly called "medhok", and there is no repetition of word itself. Different from Selogudig language, pronunciation of word same 
as pronunciation of Madurese language. If a word or phrase is pronounced using elongated rhythms and it does not abbreviate phonemes as in the language of Madurese language. There is also repetition word in Selogudig language such as Madurese language. Mostly people call Selogudig language as "bahasa Madura yang dijawakan" in English means Madurese language that is direct translated into the Javanese language.

\section{Another Important Data}

During the observation, the researcher also found another important and interesting data and information which should be explained in this research. There is repetition of word in Selogudig language same as Madurese language.

\section{Repetition of Word in Javanese Language Selogudig-an Dialect}

Repetition of word in Selogudig language are influenced by Madurese language. The repetition of word occur at the end of syllable and and the end syllable became the first syllable. For example, ron-loronan and man-eman.

The repetition of word is divided into two kinds. The first repetition is the repetition of word with suffix -an. For example, word "ron-loronan" in Selogudig language is derived from word "loro", in Indonesian language means "berdua" and in English means "both", Another example, bakumbakan and tes-protesan. Word "bakumbakan" in Selogudig language is derived from word "umbak", in
Indonesian language means "cucian" and in Eglish means"washing", Word "tes-protesan" is derived from word "protes" in Indonesian Language means "protes" and in English means "protest".

The second repetition is the repetition of word without suffix -an. For example, tet-pentet, goh-longgoh, and man-eman. Word "tet-pentet" is derived from word "pentet". in Indonesian language means"kerdil' and in English means "pygmy". Word "goh-longgoh" is derived from word "longgoh", in Indonesian language means "duduk" and in English means "sit". Word "man-eman" is derived from word "eman" in Indonesian language means "eman" and in English language means "pity".

The repetition of word do not aplly for all words of Selogudig language. There are only few words which are occured the repetition.

\section{Discussion}

From the research findings above, society of Selogudig generally call Javanese language Selogudig-an dialect as Selogudig language. At the phonological, the pronunciation of some phonemes are influenced by Madurese language. For example, phoneme /o/ and phoneme /e/. At the lexical, there are some words are origin as Selogudig language, even the words are unfamiliar for Javanese people, for example, word "coi" in English means "this" and word "magiyan" in English means "faster". And at the accent of Selogudig language is influenced by 
Madurese dialect, so, Selogudig language called as "bahasa madura yang dijawakan" in English means Madurese language that is direct translated into Javanese language. This findings inlines with what is being stated that dialect is the technical names for what American usually thinks as an accent strictly speaking, accent refer only differences as pronounciation between one varietie of language and other. But dialect refer to all of the differences of languages, those all pronounciation, word, usage and syntax (Suratmi 1996: 6). The interesting data that the researcher got during observation is the repetition of word in Selogudig language same as the repetition word on Madurese language. For exampe, goh-longgoh, man-eman, ron-turonan. This repetition is only apllied for a few words of Selogudig language.

\section{Conclusion}

This research was conducted in the field of Linguistic Analysis found in Javanese Language Selogudig-an Dialect in Selogudig Wetan village, Pajarakan sub-district, Probolinggo district. The conclusion here is presented based on the problem of the study proposed in the first chapter about the process of Javanese Language Selogudig-an Dialect form, the phonological differences of Javanese Language Selogudig-an Dialect, the lexical differences of Javanese Language Selogudig-an Dialect and accent differences Javanese Language Selogudig-an Dialect. There is also important and interesting data which should be explained in this research.

Based on the research findings and discussion presented above, society of Selogudig call the Javanese Language Selogudig-an Dialect as Selogudig language. Language of Selogudig is hereditary language which has existed since a long time ago in Selogudig village. Selogudig language caused by people who came to the Selogudig village especially Madurese people who are gave an influence in their daily language. Basically, society of Selogudig in their daily life use Javanese language, because a lot of Madurese people who live in that region, so, Selogudig language was formed. The usage of a regional language uses Javanese language but the patois (dialect) and the accent uses Madurese dialect and accent.

The accent is used in Javanese language Selogudig-an dialect (society of Selogudig call it as Selogudig language) resembles the accent in the Madurese language than the accent in Javanese language. Moreover, there is no Javanese language's accent in Selogudig language in general. A word or phrase is pronounced using elongated rhythms and it does not abbreviate phonemes as in the language of Madurese language.

\section{Suggestion}

The result of this research does not cover all about Javanese Langauge Selogudig-an Dialect. However, this is 
still far from the completeness, but by this research, at least, the researcher and the readers know that there is also one of Javanese dialect kind, namely Selogudig-an Dialect.

The researcher suggests that the readers who want to analyze Javanese Language Selogudig-an Dialect can add the theory from other sources which are not only included in this research but also from other references.

This researcher suggests to community organization in order to maintain this kind of Dialect, Selogudig-an Dialect enforced so far. The researcher hopes that this kind of Dialect, Selogudig-an Dialect is not eliminated by the rapid development of the age and affect people's live. Because, the user of this Dialect, Selogudig-an Dialect only the society of Selogudig especially only among elderly.

In addition, the researcher suggests for next researchers to conduct the Ary, D., Jacobs, L. C., Razavieh, A. (2002). Introduction to Research in Education $6^{\text {th }}$ edition. New York:Wadsworth Thomson.

Ary, D., Jacobs, L. C., Razavieh, A. (2006). Introduction to Research Education $7^{\text {th }}$ edition. USA: Wadsworth Thomson.

Aschale, A... (2013). Key Issues of Sociolinguistics. Addis Ababa University. Retrieved June 05, 2014 from http: //www. Fundamental Issues in Sociolinguistics by Alelign Aschale Libre. html

Ayatrohaedi. (2002). Pusat Pembinaan dan Pengembangan Bahasa. Jakarta: Depdikbud.

Holmes, J. (1992). An Introduction to Sociolinguistics. London: Longman.

http://kidemang.com/kbj5/index.php/makalah-pengombyong/1203-22-

Seloguding-an-di-Kabupaten-Probolinggo-Potret-Kebertahanan-SebuahEntitas-Masyarakat-Jawa-Lama-dalam-Dominasi-Madura.html. Retrieved October 14, 2014. 


\section{Jurnal Ilmiah Bahasa dan Sastra \\ ISSN : 23557083 \\ Volume 2 Nomor 2 Desember 2015}

Hudson, R., A. (1980). Sociolinguistics. Cambridge: Cambridge University Press.

Lado, R. (1978). Linguistic Accross Cultures: Applied Linguistic for Language teachers. University of Michigen Press: Ann Arbor.

Moeloeng, J., L. (1988). Metodologi Penelitian Kuantitatif. Rosdakarya: Bandung.

Moeloeng, J., L. (2004). Metodologi Penelitian Kuantitatif. Rosdakarya: Bandung.

Richard, J., and Richard, S. (2002). Longman Dictionary of Language Teaching and Applied Linguistics. London: Person Edication Limited.

Suratmi, N. (1996). Sociolinguistic. IKIP PGRI. Unpublished book.

Wardhaugh, R. (1998). An Introduction to Sociolinguistic; third edition. Blackwell.

Wardhaugh, R. (2006). An Introduction to Sociolinguistics. Hong Kong: Graphicraft Limited. 